\title{
Appendiceal Carcinoma cM0 TNM Finding v8
}

National Cancer Institute

\section{Source}

National Cancer Institute. Appendiceal Carcinoma CMO TNM Finding v8. NCI Thesaurus. Code C134042.

Appendiceal carcinoma without evidence of distant metastasis. (from AJCC 8th Ed.) 